\title{
EFEK KERJA BERSEPEDA STATIS SELAMA 45 MENIT TERHADAP PENURUNAN KADAR LOW DENSITY LIPOPROTEIN DALAM DARAH PADA MAHASISWA 2011 PROGRAM STUDI ILMU KEOLAHRAGAAN UNIVERSITAS NEGERI JAKARTA
}

\author{
Tri Astri Ratna ${ }^{1}$, \\ Dr. dr H. Junaidi, Sp.KO², Dr. Yasep Setiakarnawijaya, SKM, MKes ${ }^{2}$ \\ ${ }^{1}$ Program Studi Ilmu Keolahragaan \\ ${ }^{2}$ Fakultas Ilmu Keolahragaan Universitas Negeri Jakarta, Kampus B, Jakarta
}

\begin{abstract}
Abstrak: Penelitian skripsi ini bertujuan untuk mengetahui efek kerja bersepeda statis 45 menit terhadap penurunan kadar Low Density Lipoprotein dalam darah pada mahasiswa 2011 Program Studi Ilmu Keolahragaan Universitas Negeri Jakarta. Penelitian ini dilaksanakan di laboratorium Somatokinetika FIK UNJ, pada tanggal 12 Desember 2012. Metode yang digunakan adalah eksperimen dengan "one group pretestposttest design". Teknik pengambilan sampel menggunakan teknik purposive sampling. Sampel berjumlah 10 orang dari jumlah keseluruhan populasi 30 orang. Instrumen yang digunakan adalah Cabasmira. Teknik analisis data yang digunakan adalah statistik uji-t. Hasil perhitungan kadar low density lipoprotein awal dan akhir setelah melakukan kerja bersepeda statis diperoleh nilai selisih rata-rata (MD) 3,7 dengan nilai perbedaan standar deviasi difference (SDD) 4,81 dan nilai perbedaan standar kesalahan mean (SEMD) 1,60. Hipotesis statistik untuk tes akhir kelompok Ho ditolak jika th $\geq \mathrm{tt}$ dan Ho diterima jika th $<\mathrm{tt}$. Hasil perhitungan diperoleh th atau thitung sebesar 2,31 dan nilai tt atau tabel sebesar 2,26 dengan taraf signifikan 5\%. Dengan demikian th $\geq$ tt maka hipotesis nihil ditolak dan hipotesis kerja diterima.
\end{abstract}

Kata Kunci : Efek kerja, epeda statis, low density lipoprotein.

\section{PENDAHULUAN}

Perkembangan ilmu pengetahuan dan teknologi dewasa ini berjalan semakin pesat. Hal ini di tandai dengan diciptakannya peralatan-peralatan canggih dengan tujuan untuk mempermudah pekerjaan manusia seperti mesin cuci, lift, escalator, mobil, motor dan lain-lain. Perkembangan ini membawa perubahan pada perilaku dan gaya hidup masyarakat khususnya masyarakat di wilayah perkotaan, yang memberikan dampak positif dan dampak negatif bagi kehidupan mereka. Salah satu dampak positif perkembangan ilmu pengetahuan dan teknologi adalah dengan adanya peralatan-peralatan canggih tersebut masyarakat semakin mendapatkan banyak kemudahan

dalam melakukan segala sesuatu yang berkaitan dengan aktifitas keseharian mereka dalam waktu yang lebih singkat dan efisien. Sedangkan dampak negatif dari perkembangan ini adalah menurunnya aktifitas fisik dalam kehidupan kesehariannya. Masyarakat cenderung menjadi malas dan tidak banyak melakukan aktifitas fisik yang bermanfaat untuk menjaga kesehatan.

Fenomena ini bukan saja terjadi pada orang dewasa yang sebagian besar waktunya dihabiskan untuk kerja. Tetapi hal ini juga banyak dihadapi oleh semua 
kalangan tanpa memandang tingkatan umur, seperti pada para pelajar, mulai dari taman kanak-kanak, sampai tingkatan mahasiswa. Hal ini terlihat seakan-akan para orang tua lupa bahwa bukan dari segi pendidikan saja yang penting untuk ditingkatkan, tetapi kesegaran jasmani juga perlu diperhatikan.

Untuk memenuhi tuntutan kehidupan yang semakin tinggi tersebut, maka aktifitas yang dilalui pun semakin tinggi. Oleh karena itu masyarakat seakan berlomba untuk meningkatkan kecerdasan dalam hal pendidikan yang bersifat teoritis, tetapi mereka melupakan arti pentingnya menjaga kebugaran tubuh dan berolahraga, hal ini disebabkan karena sangat minimnya waktu luang yang mereka miliki. Selain itu, kebiasaan mengkonsumsi makanan cepat saji atau biasa di sebut dengan makanan fast food tanpa mereka sadari juga menambah masalah setelah kurangnya berolahraga, hal ini berdampak pada tubuh yang terus menerima masukan berupa makanan yang terus ditimbun di dalam tubuh tetapi tidak ada pengeluaran yang berarti sehingga komposisi didalam tubuh tidak seimbang.

Biasanya orang-orang yang kurang mempunyai aktifitas gerak yang cukup mereka mempunyai masalah pada keseimbangan kandungan lipid mereka, karena tubuh yang terus menerima masukan berupa makanan tapi tidak diimbangi dengan pengeluaran berupa aktifitas fisik maka tubuh akan menimbun sisa-sisa makanan yang tidak terbakar. Perkembangan ilmu pengetahuan dan teknologi cukup berpengaruh terhadap kegiatan sehari-hari, dan semuanya itu terlihat dari perbedaan kegiatan masingmasing masyarakat, berdasarkan pilihannya masing- masing. Efek dari kemajuan ilmu pengetahuan dan teknologi membuat sebagian masyarakat tetap berolahraga teratur dan sebagian lagi tidak berolahraga teratur. Kurang berolahraga berdampak kurangnya aktifitas otot besar yang menyebabkan lemak dalam tubuh tidak bisa dirubah menjadi energi dan akan ditimbun terus didalam tubuh.

Terlalu banyak kolesterol dalam aliran darah bisa sangat berbahaya.Kita harus mengubah gaya hidup terutama susunan menu kita serta kegiatan rutin dan kebiasaan yang membuat kesehatan kita menghadapi resiko. Komposisi didalam tubuh bisa menjadi tidak seimbang jika asupan makanan yang dikonsumsi oleh tubuh tidak memenuhi angka kecukupan gizi,karena didalam makanan banyak terdapat komponen zat gizi yang sangat dibutuhkan oleh tubuh untuk dapat melakukan proses kehidupan, karena makanan memiliki fungsi sebagai penghasil energi, membangun dan memelihara jaringan. Jika tubuh yang terus menerima masukan berupa makanan tapi tidak diimbangi dengan pengeluaran berupa aktifitas fisik maka tubuh akan menimbun sisa- sisa makanan yang tidak terbakar tadi dan akan berdampak pada keseimbangan tubuh.

Pola hidup sehat yaitu pola makanan yang terjaga dan aktifitas olahraga yang teratur. Maksud teratur disini yaitu olahraga tersebut dilakukan dalam waktu yang tetap misalnya 3 kali dalam 1 minggu dengan durasi 30-40 menit setiap kali berolahraga. Dengan begitu, manfaat yang didapat di antaranya jantung semakin sehat dan tubuh menjadi bugar. Latihan dengan takaran atau frekuensi yang tepat dapat membantu seseorang merasakan efek latihan tersebut dan berguna bagi kesehatan dirinya. Selain itu, diperlukan pula sebuah penemuan dan teknologi serta sebuah penelitian untuk meneliti penurunan kadar lemak dari masyarakat sehingga penelitian tersebut dapat dijadikan sebuah pedoman 
untuk dapat digunakan ditempat-tempat kebugaran. Peneliti juga bisa memancing kesadaran dari masyarakat itu sendiri untuk ingin berolahraga demi kesehatannya mereka sendiri, apalagi bila mereka mengetahui hasil dari manfaat olahraga yang satu kalisaja sudah memberikan efek yang baik bagi tubuh mereka.

Kondisi yang sama juga dapat dijumpai di FIK UNJ (Fakultas Ilmu Keolahragaan Universitas Negeri Jakarta). Sebagai kampus yang berlatarbelakang ilmu keolahragaaan sudah pasti aktivitas-aktivitas yang banyak dilaksanakan adalah aktivitas olahraga, di kampus ini hampir seluruh macam aktivitas olahraga bisa dijumpai. Di FIK UNJ berbagai fasilitas olahraga disediakan sebagai sarana penunjang KBM (Kegiatan Belajar Mengajar) dan latihan cabang olahraga, antara lain; ruang perkuliahan, lapangan basket, lapangan tennis, gedung serba guna, hall A, dan sebagainya. Selain itu terdapat juga MAG (Muscle Academy Gym) dan Laboratorium Somatokinetika.

Keberadaan

Laboratorium

Somatokinetika di lingkungan FIK UNJ sangat mendukung kegiatan belajar mahasiswa, selain sebagai sarana belajar juga digunakan sebagai tempat konsultasi kesehatan olahraga, karena didukung oleh dokter spesialis olahraga yang tentunya ahli dibidang olahraga. Fasilitas-fasilitas dan alat-alat olahraganya juga sangat mendukung untuk kegiatan penelitian. Dengan begitu tubuh menjadi bugar dan siap menjalankan kesibukan sehari-hari. Selain untuk menjaga kebugaran atau kesegaran tubuh orang tersebut, olahraga juga dapat dijadikan sebagai salah satu alat pengatur kesehatan, misalnya pengaturan berat badan, kadar gula dalam darah, kolesterol dan lemak tubuh.

Olahraga yang waktunya melebihi 30 menit dapat menurunkan kadar lemak (jahat) yang sangat tidak menguntungkan pada tubuh kita. Olahraga yang dapat dilakukan contohnya adalah olahraga yang bersifat aerobik seperti jogging, jalan cepat, bersepeda, berenang dan senam aerobik. Karena lemak yang tertimbun itu nantinya digunakan sebagai sumber energi bagi tubuh untuk melakukan aktifitas tersebut.

Sel-sel tubuh memerlukan kolesterol untuk bisa tumbuh dan berkembang secara mestinya. Sel-sel ini memperoleh kolesterol dari low density lipoprotein. Ketika low density lipoprotein melekat pada reseptor maka reseptor ini memungkinkan sel-sel bisa menyerap kandungan kolesterolnya. Walaupun demikian jumlah kolesterol yang bisa diserap sebuah sel ada batasannya. Kaitan olahraga dengan low density lipoprotein dalam darah ialah olahraga dapat menjaga nilai normal kadar low density lipoprotein dalam darah. Berdasarkan uraian yang telah saya kemukakan, timbul pemikiran lebih lanjut tentang dampak olahraga terhadap perubahan kadar low density lipoprotein dalam darah.

Tinjauan Pustaka. Kerja merupakan kegiatan sehari-hari yang dilakukan seseorang untuk menghasilkan, membuat atau menjalankan. Jadi kerja dapat diartikan sebagai kegiatan yang dikerjakan seseorang untuk menghasilkan sesuatu dimana sesuatu itu bisa bermanfaat bagi orang tersebut. Jadi kerja bersepeda statis dapat diartikan sesuatu yang dihasilkan dari aktifitas bersepeda. Sehingga yang dimaksud dengan kerja bersepeda statis merupakan suatu cara terbaik untuk melatih pernafasan, jantung dan kebugaran otot. Bersepeda dengan sepeda statis sama efektifnya dengan jalan dan lari untuk menjaga kesehatan otot bagian bawah tubuh. Lebih lanjut Crist Carmichael dalam bukunya "Bugar Dengan Bersepeda" mengemukakan bahwa: Merupakan cara terbaik untuk berlatih 
selama 20 menit sampai 30 menit setiap hari, 3 sampai 5 hari setiap minggu agar memperoleh kesehatan dan kebugaran Bersepeda merupakan salah satu bentuk latihan aerobik yang terbaik. Bersepeda yang baik.

Bersepeda dapat meningkatkan kualitas sistem kekebalan dengan mengijinkan tubuh untuk melindungi dirinya dari virus dan bakteri. Bersepeda adalah metode olahraga yang paling banyak memiliki manfaat untuk menguatkan sistem kekebalan tubuh. Sudah murah, bisa menghilangkan stress juga secara fisik membuat lebih sehat dan kuat. Bersepeda beberapa kali dalam seminggu merupakan cara yang menyenangkan dan cepat untuk membakar lemak dan kalori serta meningkatkan berat yang tak berlemak.

Salah satu aspek yang menarik dari olahraga bersepeda adalah kemudahannya bagi tubuh, tidak perlu terengah-engah, gerak yang berat. Hanya duduk di atas sepeda dan mengayuh pedalnya. Sepeda statis pada dasarnya sebuah sepeda yang mempunyai roda depan terbuat dari besi dengan garis tertentu, yang dihubungkan dengan pedal yang punya dua pengayuh. Sumbuh pedal terletak dibawah pusat berat badan pengayuh.

Gigi roda depan dengan gigi pedal dihubungkan dengan seutas rantai. Pada tepi roda dililitkan sebuah kulit, ujung sabuk sebelah arus dihubungkan dengan alat pengukur gesekan dan ujung lainnya dikaitkan dengan sebuah beban dalam posisi menggantung seperti katrol. Kecepatan putaran pedal dimonitor melalui speedometer atau mengikuti irama metronome.

Gerakan mengayuh pedal sepeda statis metode Astran identik dengan gerakan anggota badan bagian bawah saat lari. Secara kinesiologis kerja berlari dan mengayuh pedal sepeda statis tidak berbeda. Namun, secara fisiologis ada perbedaan, pada berlari otot tungkai bertugas mendorong tubuh dengan gaya aksi dan mengangkat berat badan pelari.

Sedangkan mengayuh sepeda statis otot tungkai hanya bertugas menggerakan tungkai untuk mengatasi gesekan roda karena berat badan telah disangga oleh sadel sepeda statis atau sadel sepeda statis telah menetralkan gaya gravitasi tubuh pengayu sepeda.

Diantara begitu banyak variasi peralatan aerobik yang tersedia untuk melengkapi home gym, sepeda statis tetap jadi pilihan utama dikebanyakan rumah-rumah. Bersepeda tidak dapat disanggah merupakan bentuk luar biasa dari latihan kerdiovaskuler. Tapi dengan melakukan diluar ruangan sering kali bersifat tidak produktif. Terdapat 2 (dua) jenis sepeda statisioner yang umum, yaitu:

\section{Brakepad}

Merupakan sebuah sepeda yang dilengkapi dengan roda berat dan sistem jangka yang diatur oleh hambatan dan tombol control yang biasanya terletak pada palang handle atau didekatnya, dan juga merupakan sepeda yang termurah.

\section{Starp Resistance}

Merupakan sepeda yang menggunakan tali nilon yang mengencangkan dan melongkarkan daerah sekitar roda. Dimana harga sedikit lebih mahal, akan tetapi dapat dikendarai lebih mulus, memiliki jangkauan daya hambatan yang lebih luas dan lebih tahan lama.

Bersepeda adalah latihan rendah impact yang memberikan pengkondisian kardiovaskuler yang sangat baik. Sepeda statis pada dasarnya merupakan sebuah sepeda yang mempunyai sebuah roda depan yang terbuat dari besi pasif dengan garis tertentu, yang dihubungkan dengan pedal yang punya dua pengayuh. Didalam bukunya "Physiological Test for Elite Atletes", Cristoper John Gore mengemukakan 
bahwa: Cycle Ergometer merupakan sebuah sepeda mesin yang mana menggunakan ergometer untuk sebuah keseimbangan, dimana penggunaan pedalnya bisa dikontrol dengan menggunakan irama metronome.

Buku lain disebutkan bahwa sepeda statis adalah sepeda yang bergerak ditempat dan digunakan untuk berolahraga. Jadi dengan beberapa pengertian yang telah disebutkan diatas, maka sepeda statis adalah sepeda yang berjalan ditempat (statis), dimana berat bebannya dapat diatur berdasarkan kemampuan seseorang serta teknik mengayuh pedalnya dapat mengikuti irama metronome. Dan ada beberapa alat yang bisa ditambahakan seperti monitor denyut jantung, pedoman jarak, waktu dan kecepatan.

Jadi maksudnya bahwa Sepeda Statis merupakan sepeda yang digerakan oleh mesin/listrik, dimana berat bebannya dapat diatur berdasarkan kemampuan seseorang serta, teknik mengayuh pedalnya dapat mengikuti irama dari metronome. Sepeda statis merupakan sepeda yang dapat memonitor latihan, mencatat waktu, jarak, dan kecepatan atau menggunakan monitor denyut jantung untuk mengikuti level latihan.

Takaran lamanya latihan untuk olahraga prestasi adalah 45-120 menit, dalam training zone. Sedangkan untuk olahraga kesehatan antara 20-30 menit dalam training zone. Latihan-latihan tidak efisien,atau kurang membuahkan hasil kalau kurang dari takaran tersebut. Bersepeda dapat meningkatkan masingmasing komponen kebugaran:

a. Kebugaran Jantung

Kebugaran jantung diukur dengan kapasitas aerobik, yaitu kemampuan untuk melakukan latihan otot besar dan seluruh badan pada tingkat intensitas yang rendah sampai tinggi untuk periode waktu yang cukup lama.

b. Komposisi Tubuh
Bersepeda aerobik beberapa kali dalam seminggu merupakan cara menyenangkan dan cepat untuk membakar lemak dan kalori. Bersepeda membuat semua otot utama tubuh bagian bawah bekerja dan dapat menghasilkan pandangan yang ramping (berotot dan tak berlemak).

c. Fleksibilitas

Fleksibilitas merupakan kemampuan untuk menggerakan otot dan anggota badan melalui rentang gerak yang penuh. Fleksibilitas menjadikan olahraga seperti bersepeda sebagai aktifitas hidup yang dapat membuat perbedaan yang nyata bagi kesehatan untuk jangka waktu yang lama.

d. Ketahanan dan Kekuatan Otot

Bersepeda meningkatkan kekuatan dan ketahanan otot, terutama otot bagian bawah tubuh. Pada umumnya, bersepeda jarak jauh dengan intensitas rendah dapat meningkatkan ketahanan otot.

Para peneliti aerobik mengatakan bahwa bersepeda sama baiknya dengan lari dan berenang untuk mendapatkan kebugaran. Spesialis obatobatan olahraga memberikan resep bersepeda karena menyebabkan tingkat kehausan anggota badan yang lebih rendah dibandingkan lari ataupun joging. Mengendarai sepeda statis memiliki beberapa keunggulan, diantaranya:

a. Jalanan yang selalu lancar

b. Latihan yang lebih efesien secara aerobik

c. Pilihan latihan yang bervarias

Bila kita mendengar kata kerja maka dalam pikiran kita terpikirkan bahwa orang tersebut sedang mengerjakan sesuatu dan bisa apa saja. Kerja merupakan aktivitas sehari-hari yang dilakukan untuk menghasilkan suatu tujuan tertentu.

Aktifitas kerja atau bekerja adalah tuntutan yang dialami oleh seluruh manusia yang masih hidup, tentu saja 
kerja disini disesuaiakan dengan kemampuan masing-masing individu yang mengerjakan hal tersebut. Bentuknya pun sangat bervariasi yaitu ringan, sedang dan berat.

Menurut kamus bahasa indonesia kata "kerja" diartikan sebagai mengerjakan, membuat atau menjalankan. Berdasarkan arti kata diatas, kerja bersepeda statis berarti diartikan sesuatu yang dihasilkan dari aktifitas bersepeda statis.

Olahraga pada dasarnya dapat dibagi menjadi dua kelompok yaitu anaerobik dan aerobik. Olahraga an-aerobik bercirikan energi kuat, cepat dan tidak tahan lama, sedangkan olahraga aerobik adalah olahraga (gerakan) yang menuntut oksigen. Aerobik berarti menggunakan oksigen. Bersepeda statis adalah salah satu bentuk olahraga aerobik. Ciri dari olahraga aerobik adalah bersifat endurance, bertahan lama dan dapat dilakukan secara terus-menerus. Olahraga aerobik melibatkan kelompok-kelompok otot besar, serta dalam waktu yang cukup lama. Karena olahraga sepeda statis membutuhkan dan menggunakan oksigen, maka tubuh terus menerus menyediakan oksigen sehingga aktifitas yang dilakukan dapat berlangsung lama.

Kolesterol adalah lemak berwarna kekuningan dan berupa seperti lilin yang diproduksi oleh tubuh kita, terutama di dalam liver (hati). Pada permukaan liver terdapat reseptor (penerima), dan low density lipoprotein cocok dengan reseptor tersebut. Ketika low density lipoprotein melekat pada reseptor maka reseptor ini memungkinkan sel-sel bisa menyerap kandungan kolesterolnya. Walaupun demikian jumlah kolesterol yang bisa diserap sebuah sel ada batasnya. Pada orang-orang yang makan banyak lemak jenuh, maka, kadar LDL dalam darahnya tinggi, dan demikian pula kadar kolesterol dalam sel.
Low Density Lipoprotein adalah lipoprotein terkecil tetapi hanya dengan satu kandungan protein terbesar dan satu lemak yang paling kecil. Low Density Lipoprotein mengandung paling banyak kolesterol dari semua lipoprotein, dan ini merupakan pengirim kolesterol utama dalam darah.

Sel-sel tubuh memerlukan kolesterol untuk bisa tumbuh dan berkembang secara semestinya. Sel-sel ini memperoleh kolesterol dari low density lipoprotein. Kolesterol dapat diperoleh dari makanan ataupun dikumpulkan di hati setalah berada didalam darah, kolesterol bergabung dengan lemak dan densitas lipoprotein yang sangat rendah. Kolesterol menemukan jalannya ke dinding arteri koroner dan membentuk kontribusi pada perkembangan plak artheroclorosis (pengerasan arteri) yang menjadi penyebab penyakit jantung.

Menurut buku sadoso, low density lipoprotein merupakan kolesterol yang mempunyai kecenderungan mengendap pada dinding-dinding pembuluh darah dan dapat menyebabkan pembendungan yang menjadi penyebab serangan penyakit jantung atau stroke serta masalah lain. Low Density Lipoprotein adalah versi kolesterol yang berbahaya yang menemukan jalannya kedalam lapisan arteri koroner, lapisan jenis ini dapat bergabung dengan oksigen dan memantapkan perkembangan plak dalam arteri. Kolesterol Low Density Lipoprotein $(L D L)$ adalah satu hal yang perlu diketahui umum bahwa Low Density Lipoprotein menyebabkan serangan terjadinya plak kolesterol pada dinding arteri dan level kolesterol Low Density Lipoprotein yang tinggi bahkan dihubungkan dengan meningkatnya resiko serangan jantung. Kolesterol adalah suatu zat yang esensial yang digunakan untuk membentuk hormon, asam empedu membarane sel dan lapisan pelindung di sekeliling 
saraf. Selain itu juga masih banyak manfaat lainnya, kolesterol terdapat dalam plasma darah dan di dalam semua sel tubuh terutama di sel-sel jaringan syaraf.

Kadar kolesterol dalam badan setiap manusia terpengaruh oleh keturunan, lingkungan, pengaturan makanan dan latihan-latihan olahraga yang kadang-kadang tidak kita sadari bahwa keadaan keturunan menyebabkan seseorang memiliki kadar kolesterol yang tinggi didalam darahnya. Kolesterol Low Density Lipoprotein mengandung lebih banyak lemak daripada protein sehingga ia akan mengambang didalam darah. Protein utama yang membentuk Low Density Lipoprotein adalah Apolipoprotein-B. Low Density Lipoprotein dianggap sebagai lemak jahat karena dapat menyebabkan penempelan kolesterol di dinding pembuluh darah. Perkembangan arteriosklerosis berawal ketika sel-sel darah putih yang secara normal terdapat dalam sistem peredaran darah mulai menyerang dinding arteri. Sel-sel darah putih menembus kelapisan dalam dan mulai menyerap tetes-tetes lemak terutama kolesterol yang memberi sel-sel darah putih meninggalkan kolesterol dibagian dasar dinding arteri karena tidak bisa mencerna kolesterol yang diserapnya itu.

Kemudian yang terjadi adalah lapisan dibawah garis pelindung arteri berangsur-angsur mulai menebal dan jumlah sel otot meningkat. Setelah beberapa waktu berlalu, selaput jaringan penghubung yang menutupi daerah itu terpengaruh oleh sklerosis. Kalau selaput ini pecah, sel-sel darah yang beredar mulai melekat ke bagian dalam yang terpengaruh. Tahap berikutnya adalah gumpalan darah dengan cepat terbentuk pada permukaan lapisan arteri yang robek. Ini dengan cepat dapat mengakibatkan penyempitan atau penyumbatan total atas arteri. Kalau arteriosklerosis terjadi dalam arteri pada otot jantung maka akan timbul kekurangan oksigen yang akut dalam otot jantung, atau terjadi serangan jantung.

Jika otot yang lebih dalam pada dinding arteri koroner terkena dan ini sering terjadi di dekat daerah yang terkena arteriosklerosis yang hanya dengan sedikit penyempitan saja sudah cukup untuk menghambat aliran darah. Ini dapat mengakibatkan berkurangnya darah yang menuju otot jantung selama sesaat dan menyebabkan rasa sakit pada jantng, kekejangan jantung yang mungkin berlangsung beberapa waktu lamanya atau terjadi dengan cepat.
Low
Density
Lipoprotein merupakan faktor penting penyebab dari Arteriosklerosis (penyumbatan pembuluh darah) yang terdapat pada usia lanjut pembentukan pembentukan deposit tebal dari kolesterol dan senyawa ester turunannya pada permukaan sebelah dalam dari pembuluh darah. Aterosklerosis segera menimbulkan kelumpuhan dan serangan infarksi koroner, yang diakibatkan oleh terganggunya aliran darah melalui pembuluh darah yang tersumbat pada otak dan jantung.

Telah dijelaskan sebelumnya kalau kolesterol lipoprotein adalah penpenyakit jantung kenaikan level Low Density Cholesterol Lipoprotein ( $L D L-C)$ dihubungkan dengan kenaikan penyakit jantung sementara High Density Cholesterol (HDL-C) level terlihat untuk melindungi alasan untuk hubungan ini tidak selalu benar.

Agaknya pengaturan makanan dan mengurangi berat badan telah pernah ditunjukkan untuk mengurangi $L D L-C$ dan kebiasaan berlatih aerobik dapat menaikan kadar HDL-C. Beberapa katagori lipid yang diharapkan oleh para peneliti yang dapat dilihat melalui tabel: 
Tabel 1. Nilai Normal Pemeriksaan Kolesterol

\begin{tabular}{cc} 
Kolesterol & Dibawah $200 \mathrm{mg} / \mathrm{dl}$ \\
\hline LDL & Dibawah $130 \mathrm{mg} / \mathrm{dl}$ \\
\hline HDL & Dibawah $45 \mathrm{mg} / \mathrm{dl}$ \\
\hline Trigliserida & Dibawah $200 \mathrm{mg} / \mathrm{dl}$
\end{tabular}

Sumber: Klinik Damayanti

Mahasiswa adalah "Maha" yang berarti tinggi dan "Siswa" yang berarti subyek pembelajar (menurut Bobbi de Porter), jadi dari segi bahasa “ mahasiswa " diartikan sebagai pelajar yang tinggi atau seseorang yang belajar di perguruan tinggi (Universitas) dimana memiliki tanggung jawab yang tinggi untuk bangsa dan negara. Karena mahasiswa memiliki kemampuan kompleks yang dapat memberikan sumbangsihnya bagi masyarakat pada lingkup mikro dan bangsa dalam lingkup makro, baik pemikiran maupun tingkah laku. Mahasiswa juga mempunyai peranan vital dalam setiap sektor kehidupan. Namun secara garis besar, setidaknya ada 3 peran dan fungsi yang sangat penting bagi mahasiwa, yaitu: Pertama, peranan moral, dunia kampus merupakan dunia di mana setiap mahasiswa dengan bebas memilih kehidupan yang mereka mau. Disinilah dituntut suatu tanggung jawab moral terhadap diri masing- masing sebagai individu untuk dapat menjalankan kehidupan yang bertanggung jawab dan sesuai dengan moral yang hidup dalam masyarakat.

Kedua, adalah peranan sosial. Selain tanggung jawab individu, mahasiswa juga memiliki peranan sosial, yaitu bahwa keberadaan dan segala perbuatannya tidak hanya bermanfaat untuk dirinya sendiri tetapi juga harus membawa manfaat bagi lingkungan sekitarnya. Ketiga, adalah peranan intelektual. Mahasiswa sebagai orang yang disebut-sebut sebagai insan intelek haruslah dapat mewujudkan status tersebut dalam ranah kehidupan nyata. Dalam arti menyadari betul bahwa fungsi dasar mahasiswa adalah bergelut dengan ilmu pengetahuan dan memberikan perubahan yang lebih baik dengan intelektualitas yang ia miliki selama menjalani pendidikan.

Dengan fungsi tersebut, tentu saja tidak dapat dipungkiri bagaimana peran besar yang diemban mahasiswa untuk mewujudkan perubahan bangsa. Ide dan pemikiran cerdas seorang mahasiswa mampu merubah paradigma yang berkembang dalam suatu kelompok dan menjadikannya terarah sesuai kepentingan bersama. Mahasiswa sepantasnya menjadi agen pemberdayaan setelah peubahan yang berperan dalam pembangunan fisik dan non fisik sebuah bangsa yang kemudian ditunjang dengan fungsi mahasiswa selanjutnya yaitu social control, kontrol budaya, kontrol masyarakat, dan kontrol individu sehingga menutup celah-celah adanya kezaliman. Mahasiswa bukan sebagai pengamat dalam peran ini, namun mahasiswa juga dituntut sebagai pelaku dalam masyarakat, karena tidak bisa dipungkiri bahwa mahasiswa merupakan bagian masyarakat. Idealnya, mahasiswa menjadi panutan dalam masyarakat, berlandaskan dengan pengetahuannya, dengan tingkat pendidikannya, norma-norma yang berlaku disekitarnya, dan pola berpikirnya.

Mahasiswa dituntut pula untuk mencari jenis-jenis pengetahuan yang lain yang dapat mendukung menjadi manusia kritis dan tanggap terhadap kejadiankejadian di sekelilingnya. Mahasiswa dengan kemampuan intelektualnya dapat berdiri sebgai control social, disini seorang mahasiswa berarti dipercaya dapat memecahkan permasalahanpermasalahan yang terjadi dengan pengetahuannya. Lebih ekstrim lagi mahasiswa dapat mengawal perubahan di lingkungan melalui intuisinya. Menyandang gelar mahasiswa merupakan 
suatu kebanggaan sekaligus tantangan. Betapa tidak, ekspektasi dan tanggung jawab yang diemban oleh mahasiswa begitu besar. Mahasiswa adalah Seorang agen pembawa perubahan. Menjadi seorang yang dapat memberikan solusi bagi permasalahan yang dihadapi oleh suatu masyarakat bangsa di berbagai belahan dunia. Didalam dunia pendidikan, mahasiswa mempunyai peranan penting dalam memainkan kualitas pendidikan. Oleh karena itu, kemajuan dunia pendidikan suatu negara dapat dilihat dari kapabilitas mahasiswanya. Maka dari itu, mahasiswa mempunyai bargaining position yang bagus di dalam masyarakat dan sebuah Negara. Jumlah mahasiswa Ilmu Keolahragaan Angkatan 2011 Fakultas Ilmu Keolahragaan berjumlah 33 mahasiswa,diantaranya 30 laki-laki dan 3 perempuan.

Kerangka Berfikir. Berolahraga rutin sangat baik untuk $\mathrm{k}$ ondisi tubuh, untuk membina pernapasan jantung dan kebugaran otot, salah satunya yaitu bersepeda. Bersepeda adalah aktifitas yang menggunakan alat, yang dinamakan sepeda atau dalam bahasa inggris lebih dikenal cycle. Baik sepeda tersebut yang bersifat statis maupun dinamis.

Aktifitas ini dapt dilakukan didalam ruangan (in door) maupun diluar ruangan (out door). Aktifitas tersebut dapat dipakai sebagai ajang kita melepas stres, bersantai, mencari kesenangan atau hobi dan tentu pula mendapatkan manfaat kesehatannya. Bersepeda Statis secara teratur dapat mengakibatkan perbaikan kondisi fisik, dan bersepeda statis juga mempunyai manfaat antara lain dapat membuat tenang, mengurangi sifat agresif, membuat tubuh tidak cepat letih dan lain-lain. Selain manfaat yang telah disebutkan di atas ternyata bersepeda statis dengan durasi 30 sampai 40 menit juga mempunyai pengaruh yang besar terhadap tubuh karena bersepeda statis dengan durasi yang telah disebutkan diatas ternyata sangat berpengaruh pada kesehatan tubuh, karena disaat waktu tersebut kandungan lemak yang terdapat ditubuh sedang diproses untuk di ubah menjadi energi, selain itu dapat juga menekan kadar low density lipoprotein ( $L D L)$ agar tidak melebihi ambang batas normal, karena apabila melebihi batas normal akan berdampak pada kesehatan, antara lain stroke, hipertensi, jantung, dan diabetes. Jadi dengan bersepeda statis 30 sampai 40 menit secara teratur dan tepat maka akan membuat pembakaran lemak yang ada ditubuh kita dapat berlangsung sehingga tubuh tidak memiliki cadangan lemak yang berlebih sehingga tubuh akan dapat mencapai berat yang proposional dan terhindar dari segala macam penyakit yang telah disebutkan diatas, jadi lemak atau lipid akan memegang peranannya jika dalam batas ambang normal.

Aktifitas seseorang menghabiskan waktu yang tidak sedikit setiap harinya sehingga banyak dari mereka yang menggunakan sisa waktunya hanya untuk beristirahat, dan otomatis minat untuk berolahraga berkurang. Kurang berolahraga berdampak kurangnya aktifitas otot besar yang menyebabkan lemak dalam tubuh tidak bisa dirubah menjadi energi dan akan ditimbun terus didalam tubuh.

\section{METODE}

Penelitian ini bertujuan untuk mengetahui efek kerja bersepeda statis selama 45 menit terhadap penurunan kolesterol Low Density Lipoprotein pada mahasiswa angkatan 2011 Program Studi Ilmu Keolahragaan Fakultas Ilmu Keolahragaan Universitas Negeri Jakarta. Metode Penelitian yang digunakan adalah metode eksperimen. Metode eksperimen menggunakan pengaruh variabel tertentu terhadap suatu kelompok dalam kondisi yang di control secara ketat. Dalam metode eksperimen terdapat kelompok 
yang disebut kelompok eksperimen, yaitu kelompok yang sengaja dipengaruhi oleh variable-variabel tertentu misalnya latihan. Di samping itu ada pula kelompok kontrol, yaitu kelompok yang tidak dipengaruhi oleh variabel-variabel itu, misalnya tidak diberi latihan itu. Adanya kelompok kontrol dimaksud sebagai pembanding sejauh manakah terjadi perubahan akibat variabel-varibel eksperimen itu.Dapat pula kelompok yang sama dijadikan sebagai kelompok eksperimen dan kelompok kontrol dengan desain penelitian menggunakan One Group "pre-test dan Post-test design". Yaitu untuk mengetahui variabel bebas dan variabel terikat, adapun yang menjadi variable bebas adalah sepeda statis selama 45 menit, sedangkan yang menjadi variabel terikatnya adalah kadar Low Density Lipoprotein.

Instrumen Penelitian. Alat penunjang tes yang digunakan:
a. Sepeda statis (Combi cycle 400)
b. Metronom
c. Polar untuk pemeriksaan denyut nadi.
d. Stopwatch
e. Peluit
f. Formulir dan alat tulis
g. Jarum
h. Tempat menaruh sample darah
i. Petugas kesehatan dari clinicheck

Teknik Pengumpulan Data. Data dikumpulkan dari hasil test darah para peserta test yang telah diketahui perubahan kadar low density lipoproteinnya dari awal test sampai akhir test dengan merubah kadar low density lipoprotein tadi menjadi serum kemudian diperiksa oleh petugas kesehatan clinichek dengan menggunakan alat yang bernama Cabasmira.

\section{HASIL DAN PEMBAHASAN}

Deskripsi Data Hasil Penelitian. Pengambilan data pada penelitian ini dilakukan terhadap 10 sampel. Dari data yang diperoleh, 2 sampel menunjukan nilai yang ekstrim dan 1 sampel menunjukan nilai yang tetap. Deskripsi data pada penelitian ini meliputi nilai hasil tes awal, nilai tertinggi, nilai terendah, nilai rata-

rata, standar deviasi, standar error, distribusi frekuensi serta histogram dari masing-masing variabel, berikut data lengkapnya.

Tabel 2. Data hasil pemeriksaan kadar low density lipoprotein

\begin{tabular}{clll}
\multirow{2}{*}{ NO } & \multirow{2}{*}{ NAMA } & \multicolumn{2}{c}{ HASIL PEMERIKSAAN } \\
\cline { 3 - 4 } & & \multicolumn{2}{c}{ LDL } \\
\cline { 3 - 4 } & & Wwal & Akhir \\
\hline 2 & Rudy Muhammad & 61 & 57 \\
\hline 3 & Adam Putro Kusumo & 133 & 58 \\
\hline 4 & Graha Pramudya & 115 & 137 \\
\hline 5 & Eris Maulana & 66 & 56 \\
\hline 6 & Hafiz Haerudin & 86 & 86 \\
\hline 7 & Tb Syarif & 91 & 93 \\
\hline 8 & Asih Nurdianto & 77 & 68 \\
\hline 9 & Yana & 97 & 86 \\
\hline 10 & Ikhwan & 113 & 110 \\
& Sumber: Hasil pengolahan data &
\end{tabular}

1. Data hasil tes awal kadar low density lipoprotein dalam darah

Data hasil tes awal yang terkumpul mengenai kadar low density lipoprotein dalam darah sebelum kerja bersepeda statis 45 menit sebagai berikut: Hasil data awal yang diperoleh dari rentang nilai terkecil $59 \mathrm{mg} / \mathrm{dl}$ dan rentang nilai terbesar $133 \mathrm{mg} / \mathrm{dl}$ didapat nilai rata-rata sebesar $89,8 \mathrm{mg} / \mathrm{dl}$, standar deviasi 24,97 dan standar error sebesar 8,32. Hal tersebut dapat dilihat pada tabel deskripsi sebagai berikut:

Tabel 3. Deskripsi data awal kadar low density lipoprotein dalam darah

\begin{tabular}{ll} 
Variabel & Tes Awal mg/dl \\
\hline Nilai Terendah & 59 \\
\hline Nilai Tertinggi & 133 \\
\hline Rata-rata & 89.8 \\
\hline Standar Deviasi & 24.97 \\
\hline Standar Error & 8.32
\end{tabular}

Sumber: Hasil pengolahan data

2. Data hasil tes awal Efek Kerja Bersepeda Statis 45 Menit 
Tabel 4. Distribusi Frekuensi Tes Awal Efek Kerja Bersepeda Statis 45 Menit

\begin{tabular}{ccccc} 
No & $\begin{array}{c}\text { Kelas } \\
\text { interval }\end{array}$ & $\begin{array}{c}\text { Titik } \\
\text { Tengah }\end{array}$ & F.A & $\begin{array}{c}\text { F.R } \\
\%\end{array}$ \\
\hline 1 & $56-80$ & 68 & 4 & 40 \\
\hline 2 & $81-105$ & 93 & 3 & 30 \\
\hline 3 & $106-130$ & 118 & 2 & 20 \\
\hline 4 & $131-155$ & 143 & 1 & 10 \\
\hline$\sum$ & & & 10 & 100
\end{tabular}

Sumber : Hasil Pengolahan Data

Dari tabel diatas rentangan nilai kadar low density lipoprotein dari nilai terendah sebesar 56 sampai dengan nilai tertinggi sebesar 155 dibuat kelas interval untuk menentukan titik tengah, frekuensi absolute dan frekuensi relatif sebagai berikut: dari kelas interval 56 sampai 80 didapati titik tengah 68 dengan frekuensi absolut 4 kali dan frekuensi relatif $40 \%$, dari kelas interval 81 sampai 105 didapati titik tengah 93 dengan frekuensi absolut 3 kali dan frekuensi relatif $30 \%$, dari kelas interval 106 sampai 130 didapati titik tengah 118 dengan frekuensi absolut 2 kali dan frekuensi relatif $20 \%$, dari kelas interval 131 sampai 155 didapati titik tengah 143 dengan frekuensi absolut 1 kali dan frekuensi relatif $10 \%$. Dan nilai kadar low density lipoprotein yang paling sering muncul adalah dari kelas interval 56 sampai 80 dengan frekuensi absolut 4 kali dan frekuensi relatif sebesar $40 \%$.

\section{Data hasil tes akhir kadar low} density lipoprotein dalam darah

Data hasil tes akhir yang terkumpul mengenai kadar low density lipoprotein dalam darah sesudah kerja bersepeda statis 45 menit sebagai berikut: Hasil data akhir yang diperoleh dari rentang nilai terkecil $56 \mathrm{mg} / \mathrm{dl}$ dan rentang nilai terbesar $137 \mathrm{mg} / \mathrm{dl}$ didapat nilai ratarata sebesar $86,1 \mathrm{mg} / \mathrm{dl}$, standar deviasi 27,18 dan standar error sebesar 9,06. Hal tersebut dapat dilihat pada tabel deskripsi sebagai berikut:
Tabel 5. Deskripsi data akhir kadar low density lipoprotein dalam darah

\begin{tabular}{cc} 
Variabel & Tes Akhir $\mathbf{~ m g / d l}$ \\
\hline Nilai Terendah & 56 \\
\hline Nilai Tertinggi & 137 \\
\hline Rata-rata & 86,1 \\
\hline Standar Deviasi & 27,18 \\
\hline Standar Error & 9,06 \\
Sumber: Hasil pengolahan data
\end{tabular}

4. Data hasil tes akhir Efek Kerja Bersepeda Statis 45 menit

Tabel 6. Distribusi frekuensi tes akhir efek kerja bersepeda statis $\mathbf{4 5}$ menit

\begin{tabular}{ccccc} 
No & Kelas interval & $\begin{array}{c}\text { Titik } \\
\text { Tengah }\end{array}$ & F.A & $\begin{array}{c}\text { F.R } \\
\%\end{array}$ \\
\hline 1 & $56-80$ & 68 & 4 & 40 \\
\hline 2 & $81-105$ & 93 & 3 & 30 \\
\hline 3 & $106-130$ & 118 & 2 & 20 \\
\hline 4 & $131-155$ & 143 & 1 & 10 \\
\hline & & $\sum$ & 10 & 100
\end{tabular}

Sumber: Hasil pengolahan data

Dari tabel diatas rentangan nilai kadar low density lipoprotein dari nilai terendah sebesar 56 sampai dengan nilai tertinggi sebesar 155 dibuat kelas interval untuk menentukan titik tengah, frekuensi absolut dan frekuensi relatif sebagai berikut :dari kelas interval 56 sampai 80 didapati titik tengah 68 dengan frekuensi absolut 4 kali dan frekuensi relatif $40 \%$, dari kelas interval 81 sampai 105 didapati titik tengah 93 dengan frekuensi absolut 3 kali dan frekuensi relatif $30 \%$, dari kelas interval 106 sampai 130 didapati titik tengah 118 dengan frekuensi absolut 2 kali dan frekuensi relatif $20 \%$, dari kelas interval 131 sampai 155 didapati titik tengah 143 dengan frekuensi absolut 1 kali dan frekuensi relatif $10 \%$. Dan nilai kadar low density lipoprotein yang paling sering muncul adalah dari kelas interval 56 sampai 80 dengan frekuensi absolut 4 kali dan frekuensi relatif sebesar $40 \%$.

\section{PENUTUP}

Kesimpulan. Berdasarkan hasil analisis data dapat disimpulkan bahwa efek kerja bersepeda statis selama 45 menit berpengaruh terhadap penurunan kadar Low Density Lipoprotein dalam darah 
pada mahasiswa ilmu keolahragaan angkatan 2011 Universitas Negeri Jakarta.

Saran. Berdasarkan hasil pengolahan data dan analisis data yang diperoleh dari penelitian ini, maka dapat disarankan sebagai berikut :

1. Menjaga pola makan dan melakukan aktifitas olahraga yang teratur minimal 3 kali dalam 1 minggu dengan durasi 30-40 menit setiap kali berolahraga.

2. Bagi para mahasiswa khususnya di FIK-UNJ dan masyarakat pada umumnya, untuk menjaga pola makanan dengan tidak mengkomsumsi makanan cepat saji dan berolahraga secara teratur.

3. Dalam penurunan kadar Low Density Lipoprotein dalam darah , maka disarankan bagi masyarakat untuk merubah gaya hidup serta kegiatan rutin agar tubuh tidak menimbun sisa-sisa makanan yang tidak terbakar.

\section{DAFTAR RUJUKAN}

Albert L. Lehninger, Dasar-dasar Biokimia Jilid I, Jakarta: Erlangga 1988

Anas Sudjiono, Pengantar Statistik Pendidikan, Jakarta: PT. Raja Grafindo Persada, 2003

Asri Del, Masnun Dadang, Hermawan Iwan, Jurnal Keolahragaan FORTIUS, Jakarta: FIK UNJ, 2004)

Brian J. Sharkey, Kebugaran dan Kesehatan. (Jakarta: P.T. Raja Grafindo Persada, 2003)

Burke Edmund R,Panduan Lengkap: Latihan Kebugaran di Rumah, Jakarta: PT Raja Grafindo, 2001

Carmichael Chris, Bugar dengan Bersepeda, Jakarta: PT Raja Grafindo, 1996

Gore Christoper John, Physiological Test for Elite Atletes (Australia Sport Commision, Human Kinetics) Australia, 2000

Junquiera L. Carlos, dkk, Histologi Dasar Edisi ke 8, Jakarta: EGC 1998
Kamus Besar Bahasa Indonesia Edisi Kedua, (Departemen Pendidikan dan Kebudayaan Balai Pustaka)

Kriyantono Rachmat, Teknis Praktis Riset Komunikasi, Kencana Preda Media, Jakarta: 2008

Lehninger Albert L, Dasar-dasar Biokimia Jilid I Jakarta: Erlangga 1988

McGowan Marry P, Menjaga Kebugaran Jantung, Jakarta: P.T Raja Grafindo, 2001

Nasution Andi Hakim, Energi dan Zat-Zat Gizi, Jakarta: PT.Gramedia, 1987

Nasution S., M.A, Metode Research, Jakarta: Bumi Angkasa, 2002

Pate, Ratella, dan Mclenaghan, Dasardasar Ilmiah Kepelatihan, Semarang: IKIP Semarang Press, 1993

Prasetyo Bambang\& Jannah Lina Mitaful, Metode Penelitian Kuantitatif (Teori dan Aplikas), Jakarta: Raja Grafindo Persada, 2005

Ross Robert M, Exercise Concepts and Calculations(Michigan: Cushing- Molloy inc 1990)

Sadoso Sumosadjuno, Pengetahuan Praktis Kesehatan Dalam Olahraga 3, Jakarta: PT Gramedia Pustaka Utama

William F Ganong, Fisiologi Kedokteran diterjemahkan Adji Dharma Edisi 20 (Jakarta, EGC: 2002)

Wojowasito S, Kamus Bahasa Indonesia. (edisi revisi: penerbit C.V)

Y.S.Santoso Giriwijoyo, Ilmu Faal Olahraga. (Bandung : FK UNPAD, 1992)

http://blog.ub.ac.id/ardi93/essay-peranmahasiswa/ diakses sabtu, 22 sep 2012

http://mimpitrigati.blogspot.com/2011/12/ hakikat-mahasiswa.html diakses selasa, 05 sep 2012

http://www.lipidword.com/content/4/1/6 diakses selasa, 06 Jun 2012. 